\title{
The Effect of Principals' Competencies on Teachers' Job Satisfaction and Work Commitment
}

\author{
Yulia Rachmawati \\ Department of Education Management, Universitas Ahmad Dahlan, Yogyakarta, \\ Indonesia ORCID: 0000-0001-6661-7255
}

Suyatno SUYATNO*

Department of Education Management, Universitas Ahmad Dahlan, Yogyakarta, Indonesia. Pramuka Street, No. 42, Sidikan, Umbulharjo, Yogyakarta, Indonesia. ORCID: 0000-0002-5796-6100

\begin{tabular}{|c|c|}
\hline Article history & The paper aims to examine the influence of a principal's managerial \\
\hline $\begin{array}{l}\text { Received: } \\
19.05 .2020\end{array}$ & $\begin{array}{l}\text { competence on teachers' job satisfaction and work commitment. The } \\
\text { study belongs to a quantitative type with a cross-sectional design. }\end{array}$ \\
\hline $\begin{array}{l}\text { Received in revised form: } \\
13.09 .2020\end{array}$ & $\begin{array}{l}\text { The samples are } 77 \text { teachers from private junior high schools in } \\
\text { Yogyakarta, all of which were selected using a random sampling } \\
\text { technique. The data were collected through a questionnaire, which }\end{array}$ \\
\hline $\begin{array}{l}\text { Accepted: } \\
13.10 .2020\end{array}$ & $\begin{array}{l}\text { has been tested for validity and reliability. The data were analyzed } \\
\text { using PLS-SEM as the samples used were less than a hundred } \\
\text { numberwise. The hypothesis testing using PLS-SEM with path }\end{array}$ \\
\hline Key words: & coefficient is accepted if the evaluation of the t-statistic is above 1.96 \\
\hline $\begin{array}{l}\text { Conceptual competency, } \\
\text { interpersonal competency, } \\
\text { technical competency, } \\
\text { work commitment, } \\
\text { job satisfaction. }\end{array}$ & $\begin{array}{l}\text { and p-value less than } 0.05 \text {. The path coefficient revealed several } \\
\text { results. First, work commitment significantly influences teachers' job } \\
\text { satisfaction. Second, a principal's conceptual competency does not } \\
\text { considerably affect the teachers' work commitment and job } \\
\text { satisfaction. Third, the principal's interpersonal competency } \\
\text { significantly influences teachers' work commitment and job } \\
\text { satisfaction. Fourth, a principal's technical competency significantly } \\
\text { affects teachers' work commitment and job satisfaction with } \\
\text { respectively. Besides, the hypothesis tested simultaneously to the } \\
\text { variables and was evaluated using R-square adjusted value path I } \\
\text { resulted in 0.762, which means the conceptual competency, } \\
\text { interpersonal competency, and technical competency simultaneously } \\
\text { influence job satisfaction up to } 76.2 \% \text {, categorized as substantial } \\
\text { (strong). Meanwhile, R-square adjusted path II is } 0.363 \text {, which means } \\
\text { that the three competencies simultaneously influence job satisfaction } \\
\text { up to } 36.3 \% \text {, categorized as weak. The findings have important } \\
\text { implications for those involved in developing teachers' } \\
\text { professionalism in that improving a principal's interpersonal and } \\
\text { technical competencies will have a positive influence on teachers' job } \\
\text { satisfaction and work commitment. }\end{array}$ \\
\hline
\end{tabular}




\section{Introduction}

Education is a productive and strategic investment in an attempt to improve human resources quality. Quality education highly determines the quality of human resources and future civilization. It can be actualized through an appropriate process, which is influenced by internal and external factors. One of the key factors for quality education is teachers' productivity and quality as the motivator of the learning process (Suyatno et al., 2019). A teacher's quality can be improved when he is highly satisfied with the environment enhancing work commitment. This way, teachers are willing and able to achieve quality learning for quality education. It is in line with the research conducted by Taurisa and Ratnawati (2012) stating that teachers' performance is influenced by two factors i.e. internal factors, such as work commitment and job satisfaction, as well as external factors, such as leadership, school culture, and work security. A research conducted by Kennerly confirms that work satisfaction is one of the crucial aspects related to teachers' performance since if teachers are satisfied, their performance will increase (as cited in Celdran, 2020, p.2). Besides, McCormick and Donohue (2019) emphasized that work motivation and performance are influenced by work commitment. The studies prove that job satisfaction and work commitment become the determinant factors of teachers' quality in an organization.

The increase in teachers' job satisfaction and work commitment can be achieved provided a school can implement appropriate school management, which can be conducted through managerial competency. Springer (2011) revealed that an organizational leader, as a manager, can increase employees' performance by implementing proper management to increase job satisfaction and work commitment. In fact, several studies have found that the strategies of an institution leader in managing the organization influences job satisfaction and work commitment of the subordinates (Celdran, 2020; Jumintono et al., 2018; Mahfouz et al., 2019; Mehrad et al., 2014; Top et al., 2015). Organizational management strategies will be effective if a principal has good managerial competency. Katz (1955) proposes that a principal's managerial competency is divided into three which are conceptual competency, technical competency, and interpersonal competency. A principal must own the aforementioned competencies to be able to optimize human resources potential and thus achieve the collective goals (Egboka et al., 2013). Other studies claim that the managerial skills of a principal have a significant correlation with the communication skills, community behavior, as well as school climate and culture (Harahap, 2017; Sabanci, 2016; Werang, 2014). Indeed, school climate and culture created by the principal will influence teachers' job satisfaction (Maryati et al., 2019). Similarly, teachers' work commitment will increase if they are in an organization with a good working climate (Fu et al., 2014).

The studies revealed that a principal's managerial competency is correlated with teachers' job satisfaction and work commitment. However, not a variety of studies in the relevant literature discusses the influence of a principal's managerial competency on teachers' job satisfaction and work commitment. With this gap spotted, the present study aims to reveal the influence of a principal's managerial competency, which consists of conceptual, technical, and interpersonal competencies, on teachers' job satisfaction and work commitment. The research findings are expected to contribute to the concept of three managerial competencies of a principal in managing the school, which lead to an increase in teachers' job satisfaction and work commitment. In addition, the results can be one of the references for other principals in arranging 
management strategies and appropriate leadership models to improve the teachers' job satisfaction and work commitment.

\section{Literature Review}

\section{Conceptual Competency of a Principal}

Conceptual competence means "the ability to see the enterprise as a whole" (Katz, 1955). It includes recognizing how the various functions of the organization depend on one another, and how changes in any one part affect all the others; and this helps visualize the relationship of the individual businesses with the industry, the community, and the political, social, and economic forces of the nation as a whole. Through recognizing these relationships and perceiving the significant elements in any situation, the administrator should be able to act in a way that advances the overall welfare of the total organization. Further, Katz (1955) also revealed that conceptual competence highly depends on the leader's ability to create and implement a concept in organizational policies. According to Thamaraiselvi (2018), a principal is required to have conceptual competency to establish the strategic vision and plans of the organization. A leader can reach the highest management on the condition that he has the necessary conceptual competency. With the help of conceptual competency, a manager can analyze the condition and the situation and overcome some problems or obstacles faced by the organization (Sidek \& Mohamad, 2014).

\section{Technical Competency of a Principal}

Katz (1955) explains that technical competency is the knowledge about the skills in accomplishing a particular task. It also refers to the knowledge and skills, which is necessary to complete a particular task. In other words, technical competency is necessary to help a principal with completing his duties (Batra \& Sharma, 2017). Technical competency includes the skills in a particular field, the ability to analyze, and the ability to use an appropriate technique (Thamaraiselvi, 2018). Seyedinejat (2014) reveals that delegating power, distributing tasks, allocating human resources, improving human resources quality, supervising, and evaluating the performance are included in this competency.

\section{Interpersonal Competency of a Principal}

Interpersonal competency or natural competency is the ability of a principal to work with other people through effective collaboration and communication, as well as the ability to motivate others (Werang, 2014). Mukarromah and Purbaningrum (2019) suggest that human skills have a huge part in management and are unique to an organization. Social skills are related to the authority of a principal in creating two-way communication between the school and society, which includes building good relations to support the productivity of the organization members.

\section{Job Satisfaction of a Teacher}

Job satisfaction occurs when work is considered meaningful to meet the needs of employees, influenced by personal factors and work environment factors (Noor \& Akhter, 2010). Yucel (2012) stated that job satisfaction positively affects affective 
commitment, continuity commitment, normative commitment, and has a negative impact on the desire to resign. Job satisfaction is necessary since higher job satisfaction will positively affect the very job. Lower satisfaction will create a negative feeling (as cited in Yucel, 2012, p.47). Job satisfaction is divided into two categories: affective and cognitive. Affective job satisfaction is a term that is linked to an individual's positive emotions who sees his job as a source of pleasure, whilst cognitive category is connected to the feelings towards salary, working environment, career development, and working hours (Dave \& Dharmesh, 2014). Smith et al. (1983) found five aspects of job satisfaction: satisfaction towards the supervision, satisfaction towards the colleagues, satisfaction towards the salary, satisfaction towards job promotion, and satisfaction towards the job.

\section{Teacher's Work Commitment}

Work commitment is a psychological relationship between an individual and the organization where he works. It determines the decision to continue or to leave the organization (Meyer \& Allen, 1991). According to Luthans, organization commitment shows loyalty and attention to the success of the organization. An organization that the employees are committed to will achieve the expected results viz. high performance, low resignation level, and short absence (as cited in Arifin et al., 2019, p.108). Meyer and Allen (1991) explain that the notion organizational commitment is divided into three categories. First, it is an affective commitment, which serves as an emotional bond between employees and the organization. Second is a continuous commitment, which appears because of financial consequences if the employee leaves the organization. The third one is normative commitment reflecting the willingness to stay at the organization or refers to an individual's obligation when he decides to stay in the organization.

\section{The Relation between a Principal's Managerial Competency and Job Satisfaction and Work Commitment}

Managerial competency is one of the factors influencing a teacher's performance. Competency shows whether an individual can or cannot do an activity supporting his performance. A principal, functioning as the top management in the school, serves to create a comfortable working environment to improve the teachers' performance, marked by the improvement of job satisfaction and work commitment. It is relevant to the research conducted by Part (as cited in Jandaghi et al., 2011, p.6853), stating that appropriate management, especially managing human resources, will improve job satisfaction and work commitment. Orebiyi (2011) concludes that management, based on effective communication between the top leader and his subordinates, is significant to improve the employees' commitment and satisfaction. Another study also reveals that visionary management leadership proves to create a positive influence on organizational commitment and job satisfaction (Top et al., 2015). The studies showed that organizational management is related to job satisfaction and organizational commitment. To implement the management, a principal's managerial competency is necessary. The managerial competency may be correlated with teachers' job satisfaction and work commitment.

A principal with conceptual competency accomplished the task as a disturbance handler. It means that the principal can anticipate the obstacles in the school development, can manage the changes, as well as creating a conducive school culture and climate for teachers and staff productivity. Therefore, it increases teachers' job 
satisfaction and work commitment. The interpersonal competencies such as empathy, social insight, charm, wisdom, diplomacy, persuasive skills, and verbal communication are necessary to develop and maintain relations among colleagues or subordinates (Yukl, 2013). Principals' technical competencies include the ability to design the working schedule and the information flow, the skills to assign the subordinates adjusting to their expertise and organizational needs, the ability to evaluate and assess the programs (analyzing the quantitative and qualitative aspects of the evaluation and projecting the organizational goals), and the skills to encourage people to work and manage the school's finance. These contribute to the working comfort that leads to the teachers' job satisfaction and commitment (Kearns et al., 2015).

The research was conducted in three private junior high schools in the Special Region of Yogyakarta. These were: one private school in Sleman Regency, one in Bantul, and one in the Yogyakarta City. In the last three years, they achieved great success in encouraging the people around the school to enroll their children there. It led to an increasing number of students per year. Besides, the teachers performed their duties accordingly, allowing the success of the programs set by the school. In the present study, the principal of each school with conceptual, managerial, and technical competencies was assumed to contribute to the teachers' performance. Maryati et al. (2019) mentioned that two factors influenced the teachers' performance namely internal (work commitment and job satisfaction) and external (principal' leadership, school culture, and work safety) factors.

Based on the theories, the hypothesis of the research includes the following:

H1: A principal's conceptual competency influence teachers' job satisfaction

H2: A principal's interpersonal competency influences teachers' job satisfaction

H3: A principal's technical competency influences teachers' job satisfaction

H4: A principal's conceptual competency influences teachers' work commitment H5: A principal's interpersonal competency influences teachers' work commitment

H6: A principal's technical competency influences teachers' work commitment

H7: Work commitment influences teachers' job satisfaction

H8: A principal's conceptual, technical, and interpersonal competencies, as well as work commitment, simultaneously influence teachers' job satisfaction.

The scheme of the research hypothesis is illustrated in figure I.

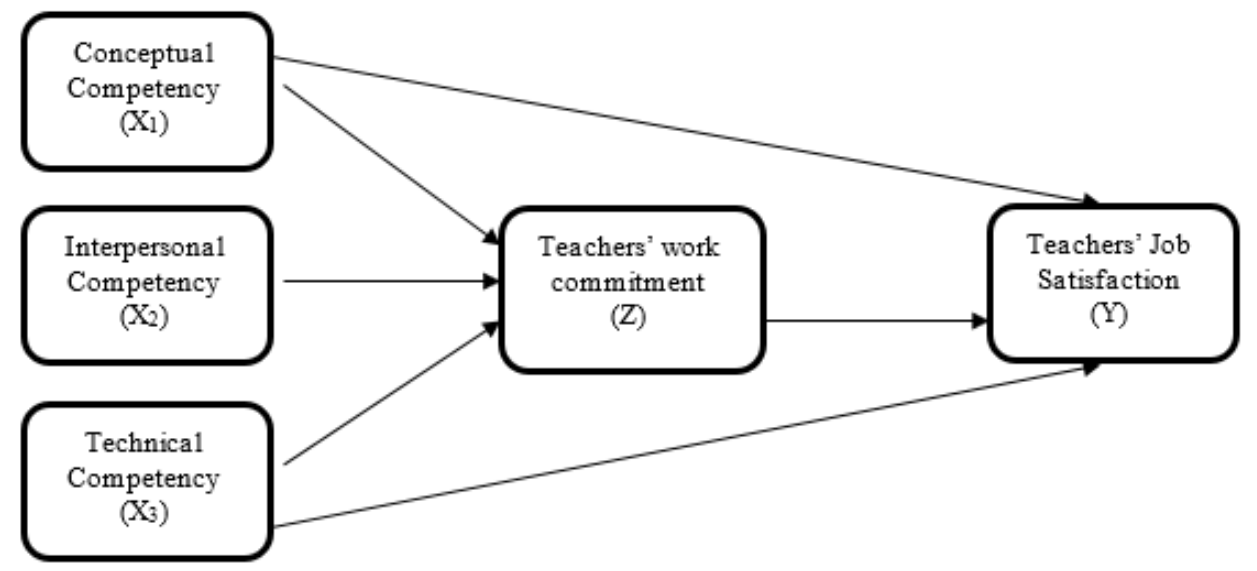

Figure 1. Hypothesis Scheme 


\section{Methods}

The research belongs to the quantitative type with a cross-sectional study. The respondents include 77 teachers from three private schools in Yogyakarta Province, one school from Sleman, one from Bantul, and one from the Yogyakarta City. They were selected using a random sampling technique. The schools were selected because the school achieved several awards, such as the healthiest school in 2005, the first winner of the school library in the province in 2012, and national Adiwiyata (environmental education) in 2013. Besides, the students in the school also achieve various awards, both national and international (Rachmawati et al., 2020). The performance was perhaps supported by the principal's leadership competencies, including conceptual, managerial, and technical aspects.

The demography of the respondents is presented in table 1 .

Table 1. Respondents' Profile

\begin{tabular}{llll}
\hline Profile & Description & Numberof Respondents & Percentage \\
\hline \multirow{2}{*}{ Gender } & Male & 49 & $63 \%$ \\
\cline { 2 - 4 } & Female & 28 & $37 \%$ \\
\hline \multirow{2}{*}{ Age } & 13 & $17 \%$ \\
\cline { 2 - 4 } & $30-39$ years old & 32 & $42 \%$ \\
\cline { 2 - 4 } & $40-49$ years old & 18 & $23 \%$ \\
\hline Highest & $50-59$ years old & 14 & $18 \%$ \\
\hline education level & $\mathrm{S} 1$ & 72 & $94 \%$ \\
\hline
\end{tabular}

The study has several variables. First is the independent variable, which is the principal's conceptual competency $\left(\mathrm{X}_{1}\right)$, principal's interpersonal competency $\left(\mathrm{X}_{2}\right)$, principal's technical competency $\left(\mathrm{X}_{3}\right)$. Second is the dependent variable, which is teachers' job satisfaction (Y). The third is the intervening variable, which is teachers' work commitment $(\mathrm{Z})$. The empiric data related to the variables were obtained through a questionnaire (close-ended) distributed to the respondents. The questionnaire consists of five parts: questionnaires about the principal's conceptual competency, the questionnaire about the principal's technical competence, the questionnaire about the principal's interpersonal competency, the questionnaire about job satisfaction, and the questionnaire about teachers' work commitment. Each uses the Likert scale model with a score of 1 to 5 in interval data. The questionnaire for the principal's managerial competency adopted skill inventory (Northouse, 2010), while the job satisfaction is adapted from Minnesota Satisfaction Questionnaire (Martins \& Proenca, 2012) and work commitment from Organizational Commitment Questionnaire or OCQ (Mowday et al., 1979). The questionnaire used level 1 for "never", 2 for "seldom," 3 for "sometimes," 4 for "often," and 5 for "always".

\section{Data Analysis}

The data were analyzed using Partial Least Square Structural Equation Modeling (PLS-SEM). It was chosen because the number of samples is less than 100. PLS-SEM is appropriate since it can answer the empirical research questions using a small number of samples (Hair et al., 2011). The data analysis using Smart PLS is carried out in two steps. It begins with evaluating the reflective and formative measurement models. The reflective evaluation includes the internal consistency test, convergence validity test, and discriminant validity test, whereas formative has the co-linearity test and 
significance of indicator relevance test. The evaluation results will be the benchmark for the next step, determining the significant relationships among the variables and hypothesis testing (Anderson \& Gerbing, 1988). The following are the analysis results conducted using PLS:

\section{Indicator Testing}

\section{Construct Reliability and Validity Test}

Table 2. Construct Reliability and Validity

\begin{tabular}{|c|c|c|c|c|}
\hline Variable & $\begin{array}{l}\text { Cronbach's } \\
\text { Alpa }\end{array}$ & $\begin{array}{l}\text { Composite } \\
\text { Reliability }\end{array}$ & AVE & Predicate \\
\hline Job Satisfaction & 0,891 & 0,911 & 0,511 & Reliable and Valid \\
\hline Work Commitment & 0,861 & 0,891 & 0,507 & Reliable and Valid \\
\hline $\begin{array}{l}\text { Interpersonal } \\
\text { Competency }\end{array}$ & 0,910 & 0,926 & 0,557 & Reliable and Valid \\
\hline $\begin{array}{l}\text { Conceptual } \\
\text { Competency }\end{array}$ & 0,899 & 0,916 & 0,525 & Reliable and Valid \\
\hline $\begin{array}{l}\text { Technical } \\
\text { Competency }\end{array}$ & 0,909 & 0,925 & 0,554 & Reliable and Valid \\
\hline
\end{tabular}

According to Nunally and Bernstein (as cited in Budhiasa, 2016, p.15), a construct is reliable if the value of Cronbach's Alpha is at least 0.60. At the same time, Chin (1998) states that the reliability is fulfilled if the score of Composite Reliability is at least 0,60 . Meanwhile, the indicator validity is reached if the average variance extracted (AVE) is above 0,50 (Hair et al., 2011). Table 2 showed that each research instrument to measure the variables, exogenous (interpersonal, conceptual, and technical competencies) and endogenous (job satisfaction, work commitment) ones, has fulfilled the reliability and validity requirements. It was evident in the score of Cronbach's Alpha and Composite reliability of each variable, which was more than 0.60 , and the average variance extracted (AVE) score was above 0.50. The instrument reliability of each variable showed that it was consistent and accountable. In addition, the research instrument was proven to produce accurate and comprehensive data about the research results.

\section{Discriminant Validity Test}

Table 3. HTMT (heterotrait-monotrait)

\begin{tabular}{llllll}
\hline Variable & $\begin{array}{l}\text { Job } \\
\text { Satisfaction }\end{array}$ & $\begin{array}{l}\text { Work } \\
\text { Commitment }\end{array}$ & $\begin{array}{l}\text { Interpersonal } \\
\text { Competency }\end{array}$ & $\begin{array}{l}\text { Conceptual } \\
\text { Competency }\end{array}$ & $\begin{array}{l}\text { Technical } \\
\text { Competency }\end{array}$ \\
\hline $\begin{array}{l}\text { Job Satisfaction } \\
\text { Work Commitment }\end{array}$ & 0,797 & & & \\
$\begin{array}{l}\text { Interpersonal } \\
\text { Competency }\end{array}$ & 0,899 & 0,628 & & \\
$\begin{array}{l}\text { Conceptual } \\
\text { Competency }\end{array}$ & 0,772 & 0,507 & 0,989 & \\
$\begin{array}{l}\text { Technical } \\
\text { Competency }\end{array}$ & 0,873 & 0,650 & 0,975 & 0,921 \\
\hline
\end{tabular}

The discriminant validity test is used to determine a construct that is empirically different from others. One of the tests is carried out using the heterotrait-monotrait (HTMT) method ratio. The discriminant validity is fulfilled if the HTMT measurement is less than 0,90 (as cited in Budhiasa, 2016, p.32). Table 3 presented the score of HTMT for most of the constructs that have fulfilled the discriminant validity because it 
was below 0.90. Conceptual - interpersonal competency, technical - interpersonal competency, and technical - conceptual competence reached an HTMT ratio of more than 0.90 . Hence, the three did not fulfill the discriminant validity, which means they are not unique.

\section{Hypothesis Testing}

\section{Path Coefficients/Direct Effect}

Hypothesis testing is carried out using Bootstrapping to path coefficient analysis. Juliandi (2018) proposes that direct effect analysis is useful to test the direct influence of an exogenous variable (independent variable) on the endogenous variable (dependent variable). If the path coefficient value is positive, the effect is one-way, and if the result is negative, the influence is contradictory. The hypothesis showing the relation among variables is accepted if the path coefficients for t-statistics above 1.96 and p-value less than 0,05 (Low et al., 2017).

Table 4. Path Coefficients to test the direct effect of exogenous variable

\begin{tabular}{lllllll}
\hline & $\begin{array}{l}\text { Original } \\
\text { Sample }\end{array}$ & $\begin{array}{l}\text { Sample } \\
\text { Mean }\end{array}$ & $\begin{array}{l}\text { Standard } \\
\text { Deviation }\end{array}$ & T statistics & P values & Hypothesis \\
\hline KMK $\rightarrow$ KPK & 0,315 & 0,313 & 0,076 & 4,132 & 0,000 & Accepted \\
KI $\rightarrow$ KPK & 0,499 & 0,484 & 0,170 & 2,938 & 0,003 & Accepted \\
KI $\rightarrow$ KMK & 0,427 & 0,408 & 0,208 & 2,058 & 0,040 & Accepted \\
KK $\rightarrow$ KPK & $-0,124$ & $-0,118$ & 0,146 & 0,851 & 0,395 & Rejected \\
KK $\rightarrow$ KMK & $-0,339$ & $-0,316$ & 0,212 & 1,600 & 0,110 & Rejected \\
KT $\rightarrow$ KPK & 0,283 & 0,298 & 0,136 & 2,091 & 0,037 & Accepted \\
KT $\rightarrow$ KMK & 0,509 & 0,518 & 0,169 & 3,003 & 0,003 & Accepted \\
\hline Notes: KMK (komitmen kerja-work commitment); KPK (kepuasan & kerja-job satisfaction); KI \\
(kompetensi interpersonal-interpersonal competency); KK (kompetensi konseptual-conceptual \\
competency); KT (kompetensi teknik-technical competency).
\end{tabular}

Table 4 revealed several results. First, KMK $\rightarrow$ KPK reached the patch coefficient 0.315 with t-statistics 4.132 and p-value 0.00 , meaning that work commitment has a positive and significant influence on job satisfaction. Second, KI $\rightarrow$ KPK reached the path coefficient 0.499 with t-statistics 2.938 and p-value 0.03 , meaning that interpersonal competency has a positive and significant influence on job satisfaction. Third, KI $\rightarrow$ KMK reached the path coefficient 0.427 with t-statistics 2.058 and p-value 0.40 , meaning that interpersonal competency has a positive and significant influence on work commitment. Fourth, KK $\rightarrow$ KPK reached the path coefficient -0.124 with t-statistics 0.851 and p-value 0.395, meaning that conceptual competency does not have a significant influence on job satisfaction. Fifth, KK $\rightarrow$ KMK reached the path coefficient 0.339 with t-statistics 1.600 and p-value 0.110 , meaning that conceptual competency does not have a significant influence on work commitment. Sixth, KT $\rightarrow$ KPK reached the path coefficient of 0.283 with t-statistics 2.091 and p-value 0.037 , meaning that technical competency has a positive and significant influence on job satisfaction. Seventh, KT $\rightarrow$ KMK reached the path coefficient 0.509 with t-statistics 3.003 and pvalue 0.003 , meaning that technical competency has a positive and significant influence on work commitment. 


\section{Indirect Effect Analysis}

According to Juliandi (2018), indirect effect analysis is useful to test the hypothesis for an indirect influence of exogenous variables on endogenous variables mediated by an intervening variable. If $\mathrm{p}$-values are less than 0.05 , there is a significant indirect effect, which means that the intervening variable mediates the exogenous and endogenous variables. Conversely, if the p-values are above 0.05 , there is no significant indirect effect. It means that the intervening variable does not mediate the variables. The results of the bootstrapping are presented in table 5 .

Table 5. Indirect Effect

\begin{tabular}{|c|c|c|c|c|c|c|}
\hline & $\begin{array}{l}\text { Original } \\
\text { Sample }\end{array}$ & $\begin{array}{l}\text { Sample } \\
\text { Mean }\end{array}$ & $\begin{array}{l}\text { Standard } \\
\text { Deviation }\end{array}$ & $\begin{array}{l}\text { T } \\
\text { statistics }\end{array}$ & $P$ values & Explanation \\
\hline KI $\rightarrow$ KPK & 0,135 & 0,130 & 0,077 & 1,750 & 0,081 & $\begin{array}{l}\text { Not } \\
\text { significant }\end{array}$ \\
\hline $\mathrm{KK} \rightarrow \mathrm{KPK}$ & $-0,107$ & $-0,099$ & 0,072 & 1,490 & 0,137 & $\begin{array}{l}\text { Not } \\
\text { significant }\end{array}$ \\
\hline $\mathrm{KT} \rightarrow \mathrm{KPK}$ & 0,160 & 0,161 & 0,063 & 2,537 & 0,011 & Significant \\
\hline
\end{tabular}

Table 5 shows several findings. First, there is no indirect effect of interpersonal competency on job satisfaction because the p-value is 0.081 , which means that work commitment, as the intervening variable, does not mediate the interpersonal competency and teachers' job satisfaction. Second, there is no indirect effect of conceptual competency on job satisfaction because the p-value is 0.137 , which means that work commitment, as the intervening variable, does not mediate the conceptual competency and teachers' job satisfaction. Third, there is an indirect effect of technical competency on job satisfaction because the p-value is 0.011 , which means that work commitment, as the intervening variable, mediates the technical competency and teachers' job satisfaction.

\section{$R$ square score Evaluation}

$\mathrm{R}$-square is the proportional measurement of the exogenous variable or independent variable that can explain the endogenous variable or dependent variable (Juliandi, 2018). The value used in the present study is R-square adjusted because it has more than one exogenous variable. The PLS Algorithm Report is presented in table 6.

Table 6. R-Square

\begin{tabular}{lll}
\hline Variable & R-Square & R-Square Adjusted \\
\hline Job Satisfaction & 0,774 & 0,762 \\
Work Commitment & 0,388 & 0,363 \\
\hline
\end{tabular}

According to Hair et al. (2011), the R-square value has different criteria in categorizing the relationship model among variables. If $\mathrm{R}$-square is 0.75 , the model is substantial (strong), R-square 0.50 is moderate (medium), and R-square 0.25 is weak. Based on table 6 , it is understood that the R-square adjusted path $\mathrm{I}$ is 0.752 , meaning that conceptual competency, interpersonal competency, and technical competency simultaneously influence the job satisfaction up to $76.2 \%$, which is substantial. Meanwhile, path II reached 0.363, meaning that the meaning that conceptual competency, interpersonal competency, and technical competency simultaneously influence job satisfaction up to $36.3 \%$, categorized as weak. The scheme for the relations among variables using SmartPLS is presented in figure 2. 


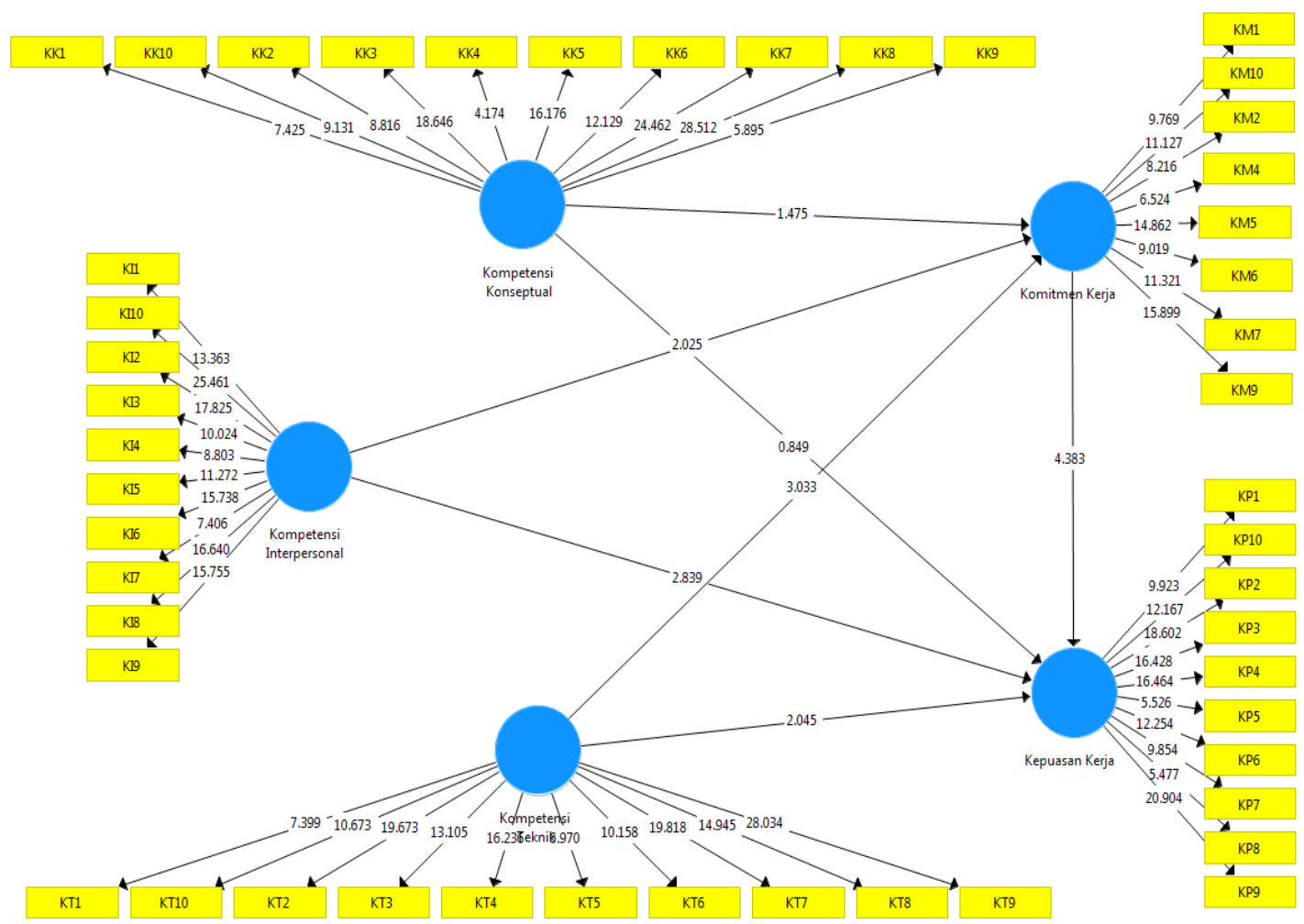

Figure 2. Scheme for the relations among research variables

\section{Discussions}

The present study answers seven hypotheses, as mentioned in the introduction. The followings are the hypothesis proven for the research.

\section{First, a principal's conceptual competency does not influence teachers' job satisfaction}

The result of the path coefficient proves that hypothesis 1 stating that a principal's conceptual competency influences job satisfaction, is rejected because the score is -0.124 with t-statistics 0.851 and p-value 0.395 . It means that conceptual competency does not influence job satisfaction. Katz (1955) suggests that conceptual competency is the skills to create a vision, strategic plans, and creativity in developing the organization. Hence, competency is the key for a leader to see the organization as a whole, leading him to overcome any problems from a systemic point of view (Mukarromah \& Purbaningrum, 2019). Based on the definition, it is clear that conceptual competency determines the future of an organization, manifested in the concept, strategic plans, and creativity. In other words, within a school, the competency is not related to and does not directly affect teachers' progress and well-being. Therefore, conceptual competency does not significantly influence teachers' job satisfaction. It is in line with the findings by Suresh and Kodikal (2015), accentuating that conceptual competency gives the least contribution, compared to technical and interpersonal competency, to support the improvement of subordinates' job satisfaction. Another research confirmed that teachers' job satisfaction does not depend on the ability of a leader in building the concept of the school. Instead, it is determined by the opportunities obtained by teachers to share their perspectives on the vision to make progress (Erdem et al., 2014). 


\section{Second, a principal's interpersonal competence has a positive and significant influence on teachers' job satisfaction}

The results of the path coefficient provide evidence that the hypothesis stating that a principal's interpersonal competency influences job satisfaction is accepted because the result of the path coefficient for the relationship between both variables is 0.499 with t-statistics 2.938 and p-value 0.003 . It means that interpersonal competency significantly and positively influences job satisfaction. The positive influence shows that the higher the principal's competency, the higher the teachers' job satisfaction. Interpersonal competency is the skill in building a good relationship with all school members. Katz (1955) states that interpersonal competency is the knowledge about human behaviour and humans' relationships with one another, including the ability to understand the feelings, to motivate communicate with others, as well as building a cooperative and effective rapport. It shows that interpersonal competency reflects the leader's behavior in managing the relationship with the subordinates - in this case, teachers. Thereupon, behavior has a significant effect on the teachers' job satisfaction. Akdol and Arikboga (2015) conclude that a leader's behavior includes trust and support for the subordinates. Further, research conducted by Cox and Manion in Orebiyi (2011) and Kituto (2011) underline that interpersonal interaction of leaders that involves communication with the employees has a significant effect on their job satisfaction. One of the factors influencing job satisfaction is the ability of a leader to motivate the subordinates. It is similar to the findings by Celdran (2020) revealing that inspirational motivation by a leader is significant to improve the subordinates' job satisfaction.

\section{Third, a principal's technical competency has a positive and significant influence on teachers' job satisfaction}

The result of the path coefficient revealed that the hypothesis, stating that a principal's technical competency influences teachers' job satisfaction, is accepted due to the fact that the score is 0.283 with t-statistics 2.091 and p-value 0.037 . It means that technical competence has a positive and significant influence on job satisfaction. The higher the competency, the higher the job satisfaction is. Sutisna (as cited in Mukarromah \& Purbaningrum, 2019, p.540) proposes that technical competency in education is the ability of a principal to understand, respond to, and be able to use learning methods, which also includes the skills to monitor the learning process conducted by the teachers along with helping them develop a learning technique. A principal's technical competency is directly related to theimprovement of teachers' quality and productivity. Some realizations of the competencies manifest in the ability of a principal to createa comfortable working climate, to provide training to improve the teachers' competency, and to delegate the tasks appropriately. The result is supported by the research by Aydin et al. (2012), showing that appraisal, promotion, supervision alongside comfortable climate highly influence teachers' job satisfaction. The newest research by Toropova et al. (2020) confirms that school climate as one of the realizations of a principal's leadership skills is closely related to teachers' job satisfaction. The more comfortable the teachers are, the more satisfied they becomewith their job. 


\section{Fourth, a principal's conceptual competency has a positive and significant influence on teachers' work commitment}

The hypothesis, stating that a principal's conceptual competence influences teachers' work commitment, is rejected showing to the fact that the path coefficient result is -0.339 with t-statistic 1.600 and $p$-value 0.110 . It means that conceptual competency influences work commitment insignificantly. Similar to job satisfaction, conceptual competency does not have a significant influence on work commitment because conceptual competency does not have an indirect effect on the teachers' psychological aspect that shapes their commitment. Dee et al. (2006) confirm that organization design and strategic plans arranged by the principal does not influence the work commitment, particularly when the principal does not involve the teachers in the process. Besides, curriculum preparation does not significantly influence teachers' work commitment (Dannetta, 2002).

\section{Fifth, a principal's interpersonal competency has a positive and significant influence on teachers' work commitment}

The hypothesis stating that a principal's interpersonal competency influences work commitment is accepted because the path coefficient score is 0.427 with $t$ statistics 2.058 and p-value 0.040 . It means that interpersonal competency has a positive and significant influence on work commitment. The positive influence shows that the improvement of interpersonal competency will improve the teachers' work commitment. Interpersonal competency has a direct and significant effect on teachers; on work commitment since the indicators of the competency influences the teachers' psychological aspect. Several indicators include the principal's roles as a motivator and role model. Besides, it is also about the principal's behaviour to all teachers, the ability to appreciate the teachers' achievement, skills to communicate and to work with the teachers, as well as to understand their condition. The results of a research by Matin et al. (2010) found that the ability to cooperate with the teachers, in particular in building a working team, is closely related to teachers' work commitment. Another study reveals that motivation coming from the principal and interpersonal communication influence the teachers' work commitment (Tansky \& Cohen, 2001).

\section{Sixth, a principal's technical competence has a positive and significant influence on teachers' work commitment}

The hypothesis stating that a principal's technical competency influences work commitment is accepted because the path coefficient score is 0.509 with t statistic 3.003 and $\mathrm{p}$-value 0.003 . It means that technical competency, positively and significantly, influences work commitment. The productivity of teachers and staff will improve along with the increase of a principal's technical competency (Prasojo, 2017). It shows that technical competency will have a significant impact on the teachers' productivity, which is also influenced by their work commitment. Technical competency refers to the quality of the supervision carried out by the principal, training for the teachers' competencies, and other facilities to help teachers improving their performance. Saha (2016) concludes that performance assessment, training, and competency development shape an employee's work commitment. The provision of training and development of teachers as part of the principal's technical competence has proven to increase the employees' self-esteem, leading to improving their work commitment to the organization (Chelliah et al., 2015). 


\section{Seventh, work commitment has a positive and significant influence on teachers' job satisfaction}

The hypothesis stating that work commitment influencing job satisfaction is accepted because the path coefficient score is 0.315 with t statistics 4.132 and p-value 0.000. It means that work commitment has a positive and significant influence on job satisfaction. The influence proves that the improvement of work commitment will also improve the teachers' job satisfaction. Organizational commitment is a bond between the individuals and the organization, which lessens the possibility of the employees to leave the organization and improve their satisfaction and comfort in the organization (Matin et al., 2010). The results also support similar studies, which found that work commitment or organizational commitment has a positive and significant correlation with job satisfaction (Gangai \& Agrawal, 2015; Kelly, 2015; Zhou et al., 2014).

\section{Eight, a principal's conceptual, interpersonal, and technical competency, as well as work commitment, simultaneously influence teachers' job satisfaction}

The analysis and interpretation of R-square adjusted results in several findings. The R-adjusted path I model scored 0.762, which means that the variables (conceptual, interpersonal, and technical competency) simultaneously influence job satisfaction up to $76.2 \%$, categorized as substantial (strong). Meanwhile, the path II model scored 0.363 , which means that conceptual, interpersonal, and technical competence, as well as work commitment, simultaneously influence job satisfaction up to $36.3 \%$, categorized as weak. Iqbal (2010) announces that a principal's managerial competency can increase teachers' work commitment. Springer (2011) mentions that managerial strategy as the manifestation of a principal's managerial competency strongly influences job satisfaction through motivation and work commitment.

\section{Conclusion}

The research resulted in five findings. First, work commitment significantly influences teachers' job satisfaction. Second, a principal's conceptual competency does not significantly affect teachers' work commitment and job satisfaction. Third, a principal's interpersonal competency significantly influences work commitment and job satisfaction. Fourth, a principal's technical competency has a significant influence on work commitment and job satisfaction. Fifth, a principal's conceptual, technical, and interpersonal competence, as well as work commitment, simultaneously influence teachers' job satisfaction. The findings show that interpersonal and technical competence have a higher effect on teachers' job satisfaction and work commitment, compared to conceptual competency. Conceptual competency does not significantly influence teachers' work commitment and job satisfaction in the three target schools. Based on the analysis of the scores obtained for the conceptual competency, it turned out that the indicator of the principal's capability in organizing the teachers is low. Hence, the principal has not had a comprehensive understanding of the concept of managing the teachers. Therefore, the teachers' work commitment and job satisfaction are influenced by other factors outside the conceptual competency of the principal. The results of the path coefficient for the independent variables display that the significant effect on work satisfaction comes from the principal's interpersonal competency. Competency refers to the principal's skills in building a relationship with the subordinates. It is comprised of the ability to communicate, to work with the subordinates, and to treat the subordinates properly. Good interpersonal competency 
means that the principal can provide comforts, which leads to the teachers' job satisfaction.

The findings suggested that the policy-makers of education (the central government, the local government, or the educational board) needs to consider the principals' interpersonal and technical competencies in planning the programs for teachers' performance improvement. The study takes a few samples from several private schools, which cannot represent the characteristics and quality of all principals in Yogyakarta. Thence, the next researchers are recommended to investigate the correlation among the variables with a more significant number of samples and to use longitudinal research because the study uses a cross-sectional design.

\section{Acknowledgment}

The researchers would like to express their most generous gratitude to the Directorate of Research and Community Development of the Ministry of Education and Cultural of the Republic of Indonesia for providing the funds in the form of a master's thesis research grant.

\section{Reference}

Akdol, B., \& Arikboga, F. S. (2015). The Effects of Leader Behavior on Job Satisfaction: A Research on Technology Fast50 Turkey Companies. Procedia - Social and Behavioral Sciences, 195, 278-282. https://doi.org/10.1016/j.sbspro.2015.06.159

Anderson, J. C., \& Gerbing, D. W. (1988). Structural Equation Modeling in Practice: A Review and Recommended Two-Step Approach. Psychological Bulletin, 103(3), 411-423. https://doi.org/10.1037/0033-2909.103.3.411

Arifin, A. H., Saputra, J., Puteh, A., \& Qamarius, I. (2019). The role of organizational culture in the relationship of personality and organization commitment on employee performance. International Journal of Innovation, Creativity and Change, 9(3), $105-129$.

Aydin, A., Uysal, S., \& Sarier, Y. (2012). The Effect of Gender on Job Satisfaction of Teachers: A Meta-Analysis Study. Procedia - Social and Behavioral Sciences, 46, 356-362. https://doi.org/10.1016/j.sbspro.2012.05.122

Batra, M. R., \& Sharma, B. P. (2017). A Perception of Managerial Skill for Leading Educational Institute. International Journal For Innovative Research In Multidisciplinary Field, 3(4), 98-103.

Budhiasa, S. (2016). Analisis Statistik Multivariate Dengan Aplikasi SEM PLS SMARTPLS 3.2.6 [Multivariate Statistical Analysis Using SEM PLS SMARTPLS 3.2.6] (J. Atmaja, Ed.; 1st ed.). Udayana Uniersity Press.

Celdran, M. C. B. (2020). Leadership styles and job satisfaction in the colleges of nursing among the universities in Zamboanga City. International Journal of Innovation, Creativity and Change, 11(7), 444-455.

Chelliah, S., Sundarapandiyan, N., \& Vinoth, B. (2015). A Research on Employees' Organisational Commitment in Organisations: A Case of SMEs in Malaysia. International Journal of Managerial Studies and Research (IJMSR), 3(7), 10-18. www.arcjournals.org

Chin, W. W. (1998). The partial least squares approach to structural equation modelling. In Marcoulides G. A. (Ed.). Modern Methods for Business Research, 295(2), 295-336. 
Dannetta, V. (2002). What Factors Influence a Teacher's Commitment to Student Learning? Leadership and Policy in Schools, 1(2), 144-171. https://doi.org/10.1076/lpos.1.2.144.5398

Dave, N., \& Dharmesh, R. (2014). A research on the factors influencing job satisfaction of MBA faculty members in Gujarat state. International Journal of Advanced Research in Computer Science and Management Studies, 2(2), 218-223.

Dee, J. R., Henkin, A. B., \& Singleton, C. A. (2006). Organizational commitment of teachers in Urban schools: Examining the effects of team structures. Urban Education, 41(6), 603-627. https://doi.org/10.1177/0042085906292512

Egboka, P. N., Ezeugbor, C. O., \& Enueme, C. P. (2013). Managerial Skills And Enhancement Strategies Of Secondary School Principals. Journal of Education and Practice, 4(26), 168-175.

Erdem, M., İlğan, A., \& Uçar, H. İ. (2014). Relationship between Learning Organization and Job Satisfaction of Primary School Teachers. International Online Journal of Educational Sciences, 6(1), 8-20. https://doi.org/10.15345/iojes.2014.01.002

$\mathrm{Fu}, \mathrm{W} .$, \& Deshpande, S. P. (2014). The Impact of Caring Climate, Job Satisfaction, and Organizational Commitment on Job Performance of Employees in a China's Insurance Company. Journal of Business Ethics, 124(2), 339-349. https://doi.org/10.1007/s10551-013-1876-y

Gangai, K. N., \& Agrawal, R. (2015). Job satisfaction and organizational commitment: Is it important for employee performance. International Journal of Management and Business Research, 5(4), 269-278.

Hair, J. F., Ringle, C. M., \& Sarstedt, M. (2011). PLS-SEM: Indeed, a silver bullet. Journal of Marketing Theory and Practice, 19(2), 139-152. https://doi.org/10.2753/MTP1069-6679190202

Harahap, F. (2017). The Influence of Principal Managerial Competency toward Teachers' Productivity and Organizational Citizenship Behavior (OCB) By Mediation of Interpersonal Communication of State Vocational High School (SMK) South Tapanuli, North Sumatera. IOSR Journal of Humanities and Social Science, 22(01), 29-39. https://doi.org/10.9790/0837-2201062939

Iqbal, A. (2010). An Empirical Assessment of Demographic Factors, Organizational Ranks, and Organizational Commitment. International Journal of Business and Management, 5(3), 16-27. https://doi.org/10.5539/ijbm.v5n3p16

Jandaghi, G., Mokhles, A., \& Bahrami, H. (2011). The impact of job security on employees , commitment and job satisfaction in Qom municipalities. African Journal of Bussines Management, 5(16), 6853-6858. https://doi.org/10.5897/AJBM10.1662

Juliandi, A. (2018). Membangun Model PLS di SmartPLS. https://doi.org/10.5281/zenodo.2538001

Jumintono, Suyatno, Zuharty, M., \& Said, H. (2018). Vocational schools leadership reinforcement model. Indian Journal of Public Health Research and Development, 9(11), 1549-1557. https://doi.org/10.5958/0976-5506.2018.01669.8

Katz, R. (1955). Skills of an Effective Administrator. In Harvard Business Review.

Kearns, K. P., Livingston, J., Scherer, S., \& McShane, L. (2015). Leadership skills as construed by nonprofit chief executives. Leadership and Organization Development Journal, 36(6), 712-727. https://doi.org/10.1108/LODJ-11-2013-0143

Kelly, J. (2015). The Relationship Between Organisational Commitment and Job Satisfaction of Commissioned Officers Within An Arm The South African National Defence Force. At the University of the Western Cape (Vol. 151, Issue 2005). https://doi.org/10.1145/3132847.3132886

Kituto, H. M. (2011). Factors That Influence Job Satisfaction Among Teaching Staff In Large Public Secondary Schools In Nairobi County (Issue October). 
Low, M. P., Ong, S. F., \& Tan, P. M. (2017). Would Internal Corporate Social Responsibility Make a Difference in Professional Service Industry Employees' Turnover Intention? A Two-Stage Approach Using PLS-SEM. Global Business \& Management Research, 9(1), 24-41. http://search.ebscohost.com/login.aspx?direct=true \&db=bth\&AN=121817964\&amp lang $=$ ja\&site $=$ ehost-live

Mahfouz, S. A., Awang, Z., \& Muda, H. (2019). The impact of transformational leadership on employee commitment in the construction industry. International Journal of Innovation, Creativity and Change, 7(10), 151-167.

Martins, H., \& Proenca, T. (2012). Minnesota Satisfaction Questionnaire - Psychometric Properties and Validation in a Population of Portuguese Hospital Workers (Issue October).

Maryati, T., Astuti, R. J., \& Udin, U. (2019). The effect of spiritual leadership and organizational culture on employee performance: The mediating role of job satisfaction. International Journal of Innovation, Creativity and Change, 9(3), 130143.

Matin, H. Z., Jandaghi, G., Karimi, F. H., \& Hamidizadeh, A. (2010). Relationship between interpersonal communication skills and organizational commitment (Case study: Jahad keshavarzi and university of Qom, Iran). European Journal of Social Sciences, 13(3), 387-398.

McCormick, L., \& Donohue, R. (2019). Antecedents of affective and normative commitment of organisational volunteers. International Journal of Human Resource Management, 30(18), 2581-2604. https://doi.org/10.1080/09585192.2016.1166388

Mehrad, A., \& Fallahi, B. (2014). The role of leadership styles on staff's job satisfaction in public organizations. Acta Universitaria, 24(5), 27-32. https://doi.org/10.15174/au.2014.597

Meyer, J. P., \& Allen, N. J. (1991). A Three-Component Conceptualization of Organizational Commitment. Human Resource Management Review, 1(1).

Mowday, R. T., Steers, R. M., \& Porter, L. W. (1979). The Measurement of Organizational Commitment. Journal of Vocational Behaviour, 14, 224-247.

Mukarromah, I., \& Purbaningrum, E. (2019). The Effect of Managerial Skills ( Conceptual, Human, and Technical ) of Headmasters to the Effectiveness of Islamic Senior High Schools in Jombang District. International Journal for Educational and Vocational Studies, 1(6), 539-544.

Noor, M., \& Akhter, M. (2010). Supervision, Salary, and Opportunities for Promotion as Related to Job Satisfaction. ASA University Review, 4(1), 255-261.

Northouse, P. G. (2010). Leadership Theory And Practice (Fifth Edition).

Orebiyi, A. ., \& Orebiyi, T. . (2011). The Influence Of Interpersonal Communication On Secondary School Teacher's Job Satisfaction And Commitment In Kogi State, Nigeria. Journal of Communication and Culture: International Perspective, 2(1), $109-117$.

Prasojo, L. (2017). Manajemen Human Capital [Human Capital Management] (Fitriyanti, Ed.; 1st ed.). UNY Press.

Rachmawati, Y., Suyatno, Santosa, A. B. (2020). Principal's Managerial Competence in Actualizing a Creative School. Universal Journal of Educational Research, 8 (8), p. 3406-3416

Sabanci, A. (2016). The Correlation between School Managers' Communication Skills and School Culture, International Journal of Progressive Education. ERIC, 12(3), 17.

Saha, R. (2016). Factors influencing Organizational Commitment - Research and Lessons. Management Research and Practice, 8(3), 36-48. 
Seyedinejat, S. S. (2014). Prioritizing Managerial Skills Based on Katz's Theory Cast Study: The Managers of Sports And Youth In Mazandaran Province. Pamukkale Journal of Sport Sciences, 5(1), 33-47.

Sidek, S., \& Mohamad, M. R. (2014). Managerial competencies and small business growth: empirical evidence from microfinance participants. International Journal of Management Studies, 21(1), 39-59.

Smith, C. A., Organ, D. W., \& Near, J. P. (1983). Organizational citizenship behavior: Its nature and antecedents. Journal of Applied Psychology, 68(4), 653-663.

Springer, G. J. (2011). A Study of Job Motivation, Satisfaction, and Performance among Bank Employees. The Journal of Global Business Issues, 5(1).

Suresh, S., \& Kodikal, R. (2015). Managerial Skills and Job Satisfaction : a Study Among Nurses in the Healthcare Sector. International Journal of Business Economics \& Management Research, 5(July 2017).

Suyatno, Wantini, Baidi, \& Amurdawati, G. (2019). The influence of values and achievement motivation on teacher professionalism at Muhammadiyah 2 high school Yogyakarta, Indonesia. Pedagogika, 133(1), 105-127. https://doi.org/10.15823/p.2019.133.6

Tansky, J. W., \& Cohen, D. J. (2001). The relationship between organizational support, employee development, and organizational commitment: An empirical study. Human Resource Development Quarterly, 12(3), 285-300. https://doi.org/10.1002/hrdq.15

Taurisa, C. M., \& Ratnawati, I. (2012). Analisis Pengaruh Budaya Organisasi dan Kepuasan Kerja terhadap Komitmen Organisasional dalam meningkatkan Kinerja Karyawan [Analysis of Effect of Organizational Culture and Organizational Commitment on Job Satisfaction in Improving The Performance of Employment]. Jurnal Bisnis Dan Ekonomi (JBE), 19(2), 170-187. https://doi.org/ISSN: 1412-3126

Thamaraiselvi. (2018). Leadership Management Skills And Competencies For Academic Library Leaders In The Digital Environment. Journal of Social Science and Humanities Research, 3(4), 123-134.

Top, M., Akdere, M., \& Tarcan, M. (2015). Examining transformational leadership, job satisfaction, organizational commitment, and organizational trust in Turkish hospitals: public servants versus private-sector employees. International Journal of Human Resource Management, 26(9), 1259-1282. https://doi.org/10.1080/09585192.2014.939987

Toropova, A., Myrberg, E., \& Johansson, S. (2020). Teacher job satisfaction: the importance of school working conditions and teacher characteristics. Educational Review, O0(00), 1-27. https://doi.org/10.1080/00131911.2019.1705247

Werang, B. R. (2014). Principals ' Managerial Skills, School Organizational Climate, and Teachers' Work Morale at State Senior High Schools in Merauke Regency-PapuaIndonesia. International Journal of Science and Research (IJSR), 3(6), 691-695.

Yücel, I. (2012). Examining the Relationships among Job Satisfaction, Organizational Commitment, and Turnover Intention: An Empirical Study. International Journal of Business and Management, 7(20), 44-58. https://doi.org/10.5539/ijbm.v7n20p44

Yukl, G. A. (2013). Leadership In Organizations (Global Edition). In Essex: Pearson.

Zhou, J., Plaisent, M., Zheng, L., \& Bernard, P. (2014). Psychological Contract, Organizational Commitment, and Work Satisfaction: Survey of Researchers in Chinese State-Owned Engineering Research Institutions. Open Journal of Social Sciences, 02(09), 217-225. https://doi.org/10.4236/jss.2014.29037 